\title{
Analisis Kemampuan Siswa SD dalam Menyelesaikan Soal Geometri Asesmen Kompetensi Minimum
}

\author{
Desi Ratna Sari ${ }^{1 *}$, Epon Nur'aeni Lukman ${ }^{2}$, Muhammad Rijal Wahid Muharram ${ }^{3}$ \\ ${ }^{123}$ PGSD Universitas Pendidikan Indonesia, Jl. Dadaha Nomor 8, Tasikmalaya, Jawa Barat \\ Corresponding author's : desiratna@upi.edu
}

\section{Analysis of Elementary School Students' Ability in Solving Geometry Problems Minimum Competency Assessmen}

\begin{tabular}{l} 
Kata Kunci \\
\hline AKM-Numerasi, \\
Kemampuan Siswa, \\
Soal Geometri
\end{tabular}

\section{Keywords:}

AKM-Numeration,

Student Ability, Geometry Problem

\begin{abstract}
Abstrak
Pelaksanaan Asesmen Kompetensi Minimum (AKM) yang akan diselenggarakan pada jenjang pendidikan sekolah, khususnya dijenjang pendidikan Sekolah Dasar membutuhkan persiapan dalam rangka menyelenggarakannya. Salah satu komponen yang harus disiapkan diantaranya siswa. Kesiapan aspek siswa dalam hal ini dipandang sangat penting karena sebagai subjek yang akan diujikan dalam pelaksanaan Asesmen Kompetensi Minimum (AKM). Kompetensi mendasar yang diujikan kepada siswa terbagi ke dalam 2 kompetensi yaitu literasi membaca dan numerasi. Salah satu lingkup materi pada AKM Numerasi yang diujikan adalah geometri. Penelitian ini membahas mengenai analisis kemampuan siswa sekolah dasar dalam menyelesaikan soal geometri pada Asesmen Kompetensi Minimum Numerasi. Penelitian ini bertujuan untuk melihat dan mendeskripsikan kemampuan siswa kelas IV dalam menyelesaikan soal geometri pada AKM Numerasi ditinjau dari kualitas respon siswa berdasarkan hasil ketuntasan siswa dalam menyelesaikan tes. Penelitian ini menggunakan metode deskripsi kualitatif. Data diperoleh dari hasil tes dan wawancara dari siswa kelas IV di lingkungan warga RT 04 Pasirjaya Kota Tasikmalaya. Terdapat 1 siswa kelas IV yang menjadi subjek penelitian ini. Hasil penelitian ini menunjukkan bahwa kemampuan siswa tersebut dalam menyelesaikan soal geometri pada Asesmen Kompetensi Minimum Numerasi tergolong rendah yaitu dengan presentase sebesar $17,65 \%$.
\end{abstract}

\section{Abstract:}

Implementation of the Minimum Competency Assessment (AKM) which will be held at the school education level, especially at the elementary school education level requires preparation in order to carry it out. One of the components that must be prepared are students. The readiness of the student aspect in this case is seen as very important because it is a subject that will be tested in the implementation of the Minimum Competency Assessment (AKM). The basic competencies that are tested on students are divided into 2 competencies, namely reading literacy and numeracy. One of the scopes of the material in the Numeration AKM that is tested is geometry. This study discusses the analysis of the ability of elementary school students in solving geometry problems in the Minimum Numeration Competency Assessment. This study aims to see and describe the ability of fourth grade students in solving geometry problems in the AKM Numeration in terms of the quality of student responses based on the results of students' completeness in completing the test. This study uses a qualitative description method. The data were obtained from the results of tests and interviews with fourth grade students in the neighborhood of RT 04 Pasirjaya, Tasikmalaya City. There is 1 grade IV student who is the subject of this research. The results of this study indicate that the student's ability to solve geometry problems in the Minimum Numeration Competency Assessment is relatively low, with a percentage of $17.65 \%$. 


\section{PENDAHULUAN}

Matematika adalah satu mata pelajaran yang diajarkan di sekolah, baik untuk tingkatan SD, SMP, dan SMA/sederajat. Urgensi mempelajari matematika berhubungan dengan pemecahan masalah sehari-hari. Konsep-konsep yang ada di dalam matematika erat kaitannya dengan lingkungan sehari-hari. Geometri diidentifikasi sebagai bagian dari cabang matematika. Menurut Usiskin (dalam Nur'aeni 2008:124) Geometri merupakan satu-satunya ilmu yang dapat mengaitkan matematika dengan bentuk fisik dunia nyata, geometri satu-satunya yang memungkinkan ide-ide dari bidang matematika yang lain untuk di gambar, serta geometri dapat memberikan contoh yang tidak tunggal tentang sistem matematika. Nur'aeni (2008) berpendapat bahwa peran geometri di jajaran bidang studi matematika sangat kuat, bukan saja karena geometri mampu membina proses berpikir siswa, tapi juga sangat mendukung banyak topik lain dalam matematika. Namun, fakta di lapangan masih banyak siswa yang beranggapan bahwa matematika adalah sesuatu hal yang sulit, sukar dipelajari, dan bahkan cenderung menyerah terlebih dahulu. Hal ini umumnya lazim ditemukan dalam setiap kelas pembelajaran matematika. Nur'aeni (2008) menyatakan bahwa kenyataan di lapangan, memperlihatkan bahwa di antara semua cabang matematika, hasil belajar siswa dalam geometri yang sangat memprihatinkan. Hal ini terlihat dari beberapa penelitian yang telah dilakukan sebelumnya. Herawati (dalam Nur'aeni 2008: 125) melaporkan hasil penelitiannya bahwa masih banyak siswa sekolah dasar yang belum memahami konsep-konsep dasar geometri.

Asesmen Kompetensi Minimum (AKM) merupakan penilaian kompetensi mendasar yang diperlukan oleh semua murid untuk mampu mengembangkan kapasitas diri dan berpartisipasi positif pada masyarakat (Kemdikbud, 2020). Penilaian dalam AKM ini terhimpun dalam 2 rumpun kategori meliputi Literasi dan Numerasi. Numerasi merupakan salah satu literasi pada bidang matematika. Numerasi adalah kemampuan berpikir menggunakan konsep, prosedur, fakta, dan alat matematika untuk menyelesaikan masalah sehari-hari pada berbagai jenis konteks yang relevan untuk individu sebagai warga negara Indonesia dan dunia (Kemdikbud, 2020). Penggunaan konteks pada AKM Numerasi digunakan untuk mengenali peran matematika dalam kehidupan sehari-hari. Menurut Maulidina (dalam Hartatik 2019:33) siswa dengan kemampuan matematika tinggi mampu menggunakan berbagai macam angka atau simbol yang terkait matematika dasar untuk memecahkan masalah matematika, mampu menganalisis informasi dalam bentuk grafik, tabel, bagan dan lainnya dan menggunakan informasi tersebut dalam menyelesaikan masalah. Oleh karena itu, siswa dengan numerasi yang tinggi akan mampu memecahkan masalah-masalah matematika dengan baik, sehingga pembelajaran matematika bermanfaat bagi diri siswa khususnya. Dengan demikian, penyusunan desain soal AKM Numerasi disusun berbasis konteks dalam kehidupan sehari-hari (Asrijanty dalam Cahyanovianty 2021: 1441).

Dari pemaparan tersebut, peneliti tertarik untuk melakukan penelitian dengan judul “ Analisis Kemampuan Siswa dalam Menyelesaikan Soal Geometri pada Asesmen Kompetensi Minimum Numerasi di Sekolah Dasar. Guna untuk mengetahui kemampuan siswa dalam menyelesaikan soal AKM sehingga dapat dijadikan acuan sebagai perbaikan mutu pembelajaran serta kesiapan peserta didik dalam menghadapi soal AKM.

\section{METODE PENELITIAN}

Jenis penelitian ini adalah deskriptif kualitatif. Subjek penelitian ini adalah siswa kelas IV di lingkungan warga RT 04 Pasirjaya Kota Tasikmalaya. Pelaksanaan tes dilakukan selama 60 menit. Pelaksanaan tes untuk mengkategorikan kemampuan siswa dalam menyelesaikan soal geometri AKM Numerasi. Tes dilakukan secara mandiri untuk mendapat hasil yang sesuai dan diawasi oleh peneliti. Setelah selesai, hasil tes dikumpulkan dan dikoreksi, kemudian hasil tes dikategorikan ke dalam tingkatan kategori rendah, sedang atau tinggi.

Tabel 1. Interval Nilai dari tiap-tiap kategori

\begin{tabular}{l|l}
\hline \multicolumn{1}{c|}{ Interval Nilai } & \multicolumn{1}{c}{ Kategori } \\
\hline$\leq 40$ & Rendah \\
\hline $41-70$ & Sedang \\
\hline$\geq 71$ & Tinggi \\
\hline
\end{tabular}

Sumber: Ma'sum (dalam Khoirudin, A., dkk: 2017: 35)

Setelah siswa tergolongkan pada kategori tingkatan, peneliti melakukan wawancara. Wawancara dilakukan dengan mengacu pada pedoman wawancara yang telah di validasi. Hal ini dilakukan untuk memperkuat data kemampuan numerasi yang dimiliki oleh siswa. Teknik 
analisis data dilaksanakan secara deskriptif yaitu mendeskripsikan serta menguraikan hasil tes dan wawancara siswa.

\section{HASIL DAN PEMBAHASAN}

Berdasarkan hasil penelitian yang dilakukan di lingkungan warga RT 04 Pasirjaya Kota Tasikmalaya didapat hasil bahwa kemampuan siswa kelas IV dalam menyelesaikan soal geometri pada AKM Numerasi diwilayah tersebut berada dalam kategori rendah karena ada di bawah interval nilai $\leq 40 \%$ yaitu sebesar $17.56 \%$. Dari 14 soal geometri AKM Numerasi yang diberikan kepada siswa, yaitu yang terdiri dari 4 soal Pilihan Ganda (PG), 4 soal Pilihan Ganda Kompleks (PGK) dan 6 soal Uraian dengan skor maksimal sebesar 17 poin, siswa hanya mampu menjawab benar 3 soal yaitu pada 1 soal PG (Pilihan Ganda) dan 2 soal PGK (Pilihan Ganda Kompleks) dengan memperoleh skor sebanyak 3 poin dari total 17 poin. Adapun pada soal uraian, siswa mengalami kesulitan dalam menyelesaikannya disebabkan siswa kurang memahami isi soal dan tidak dapat menjawab secara maksimal.

Berikut hasil pengerjaan tes soal geometri pada AKM Numerasi yang dilakukan oleh siswa.

Tabel 1. Hasil dari Instrumen Tes Soal Geomteri AKM Numerasi

\begin{tabular}{|c|c|c|c|c|c|c|c|c|c|c|c|c|c|c|c|c|c|c|}
\hline \multicolumn{18}{|c|}{ KEMAMPUAN NUMERASI SISWA PADA AKM NUMERASI } & \multirow{4}{*}{ Ket. } \\
\hline \multirow{3}{*}{$\begin{array}{l}\mathbf{N} \\
\mathbf{0}\end{array}$} & \multirow{3}{*}{$\begin{array}{c}\text { Nam } \\
\text { a } \\
\text { Sisw } \\
\text { a }\end{array}$} & \multicolumn{14}{|c|}{ Soal Geomteri AKM Numerasi SD } & \multirow{3}{*}{ Skor } & \multirow{3}{*}{$\begin{array}{l}\text { Jenis } \\
\text { Kemam } \\
\text {-puan }\end{array}$} & \\
\hline & & $\begin{array}{l}P \\
G\end{array}$ & \multicolumn{4}{|c|}{ PGK } & \multicolumn{6}{|c|}{ Uraian } & \multicolumn{3}{|c|}{ PG } & & & \\
\hline & & 1 & 2 & 3 & 4 & 5 & 6 & 7 & 8 & 9 & $\begin{array}{l}1 \\
0\end{array}$ & $\begin{array}{l}1 \\
1\end{array}$ & $\begin{array}{l}1 \\
2\end{array}$ & $\begin{array}{l}1 \\
3\end{array}$ & $\begin{array}{l}1 \\
4\end{array}$ & & & \\
\hline & & 1 & 1 & 2 & 2 & 2 & 1 & 1 & 1 & 1 & 1 & 1 & 1 & 1 & 1 & 17 & & $\begin{array}{l}\text { Skor } \\
\text { Max. }\end{array}$ \\
\hline 1 & VA & 0 & 0 & 1 & 1 & 0 & 0 & 0 & 0 & 0 & 0 & 0 & 0 & 0 & 1 & 3 & Rendah & - \\
\hline
\end{tabular}

Sumber: Hasil tes penelitian

Setelah dilakukan tes, peneliti melakukan wawancara kepada siswa untuk memperkuat data penelitian. Peneliti mengajukan beberapa pertanyaan kepada siswa. Siswa tersebut memaparkan bahwa ia belum memperoleh informasi AKM Numerasi dengan jelas terutama dalam hal teknik pengerjaan soal Pilihan Ganda Kompleks yang memiliki jawaban lebih dari satu dan tidak menggunakan opsi abjad. Siswa tersebut juga mengatakan bahwa ia baru pertama kali memperoleh dan menyelesaikan soal geometri pada AKM Numerasi. Ia mengaku kesulitan dalam menjawab soal uraian karena kurang memahami isi soal. Dengan demikian, berdasarkan paparan hasil tes dan wawancara yang dilakukan kepada siswa dapat disimpulkan bahwa kemampuan numerasi pada siswa tersebut dalam menyelesaikan soal geometri pada AKM Numerasi tergolong rendah.

\section{KESIMPULAN}

Berdasarkan hasil penelitian, peneliti menyimpulkan bahwa kemampuan siswa dalam menyelesaikan soal geometri AKM Numerasi tergolong rendah serta siswa memerlukan persiapan lebih lanjut untuk menghadapi AKM. Hal ini terlihat dari hasil jawaban yang diberikan siswa dalam menjawab soal geomteri AKM Numerasi serta menjawab wawancara yang dilakukan. Dari hasil penelitian melalui tes dan wawancara kepada siswa kelas IV di lingkungan warga RT 04 Pasirjaya kota Tasikmalaya peneliti menyarankan perlu adanya sosialisasi AKM terhadap siswa serta pendampingan khusus dalam hal mengerjakan variasi latihan soal-soal AKM. Sehingga siswa diharapkan siap menghadapi Asemsen Kompetensi Minimum yang akan dilaksanakan.

\section{DAFTAR PUSTAKA}

Cahyanovianty, A. D., \& Wahidin, W. (2021). Analisis Kemampan Numerasi Peserta Didik Kelas VIII dalam Menyelesaikan Soal Asesmen Kompetensi Minimum (AKM). Jurnal Cendekia: Jurnal Pendidikan Matematika, 5(2), 1439-1448.

Hartatik, S., \& Nafiah, N. (2020). Kemampuan Numerasi Mahasiswa Pendidikan Profesi Guru Sekolah Dasar dalam Menyelesaikan Masalah Matematika. Education and Human Development Journal, 5(1), 32-42. 
Kemdikbud (2020). Desain Pengembangan Soal Asesmen Kompetensi Minimum 2020. Jakarta: Kementrian Pendidikan dan Kebudayaan.

Kemdikbud (2020). AKM dan Implikasinya pada Pembelajaran. Jakarta: Kementrian Pendidikan dan Kebudayaan.

Nur'aeni, E. (2008). Teori Van hiele Dan Komunikasi Matematik (Apa, Mengapa dan Bagaimana). Semnas Matematika dan Pendidikan Matematika, 2-138.

Styawati, R. D., \& Nursyahida, F. (2017). Profil Kemampuan Literasi Matematika Siswa Berkemampuan Matematis Rendah Dalam Menyelesaikan Soal Berbentuk PISA. AKSIOMA: Jurnal Matematika dan Pendidikan Matematika, 8(2), 33-42. 